\title{
Yoksulluk ve Yoksulluk Geçişlerinin Belirleyenleri: Türkiye Örneği
}

Başak DALGIÇ, Department of Public Finance, Faculty of Economics and Administrative Sciences, Hacettepe University,Turkey; e-mail: basakcakar@hacettepe.edu.tr

Pelin VAROL IYIDOĞAN, Department of Public Finance, Faculty of Economics and Administrative Sciences, Hacettepe University, Turkey; e-mail:pelinv@hacettepe.edu.tr

Aytekin GÜVEN, Department of Economics, Faculty of Economics and Administrative Sciences, Abant Izzet

Baysal University, Turkey; e-mail: guven_a1@ibu.edu.tr

\section{Poverty and the Determinants of Poverty Transitions: The Case of Turkey}

\begin{abstract}
Using SILC data, we present a general framework for the distribution of poverty in Turkey, over the period 2005-11 in terms of various household characteristics. We further examine those factors in affecting households' probability of poverty entries and exits. The household characteristics explored in this study are age, education, employment status, social security registration, health status, household size, household composition and, income acquisition status. Consistent with the existing literature, our results indicate that in Turkey, poverty distribution differentiates according to various socio-economic factors, while these factors significantly affect the dynamics of poverty entries and poverty exits.
\end{abstract}

Keywords : $\quad$ Poverty, Poverty Transitions, Turkey.

JEL Classification Codes : $\quad$ D31, I32, I38.

$\ddot{\mathbf{O} z}$

$\mathrm{Bu}$ çalışmada, TÜİK tarafindan düzenlenen Gelir ve Yaşam Koşulları Anketlerinden faydalanarak, 2005-11 döneminde, Türkiye'de yoksulluğun fert ve haneye ilişkin çeşitli değişkenlere göre dağılımını ele almaktayız. Daha sonra, yoksulluktan çıkışta ve yoksul olma durumuna geçişte söz konusu faktörlerin ne yönde ve ne kadar etkili olduğunu incelemekteyiz. Çalışma boyunca üzerinde durulan fert ve hane özellikleri; yaş, cinsiyet, eğitim durumu, istihdam durumu, sosyal güvelik sistemine kayıtlılık, sağlık durumu, hanenin büyüklüğü ve hanenin gelir edinme durumudur. Çalışmanın sonuçları; var olan literatürle tutarlı olarak, Türkiye'de yoksulluk dağılımının birey ve haneye ilişkin çeşitli sosyo-ekonomik özelliklere göre farklılaştığını ve ilgili faktörlerin yoksulluktan çıkış ve yoksulluğa giriş dinamikleri üzerinde oldukça etkili olduğunu ortaya koymaktadır.

Anahtar Sözcükler $\quad$ : Yoksulluk, Yoksulluk Geçişleri, Türkiye. 


\section{Giriş}

Birleşmiş Milletler tarafından yapılan tanımlamaya göre yoksulluk; bireyin beslenme, giyinme, eğitim ve sağlık hizmetlerine ulaşabilme gibi temel ihtiyaçlarını karşılayamaması durumu olarak ifade edilebilir. Genel olarak günlük 1 doların altında gelire sahip olanlar mutlak yoksul sayılmaktadırlar. Bu tanım 1990'lı yıllarda geliștirilmiş olup çoğu ülkede kullanılmıştır. Ancak Dünya Bankası yeni uluslararası yoksulluk sınırını 2005 yılı için 1.25 dolar olarak tanımlamıştır. Bu parasal tanımlamanın yanı sıra mutlak yoksulluk; yiyecek, temiz su, sağlık, barınma, eğitim ve bilgi gibi temel insan ihtiyaçlarına erişememe durumunu ifade eder. (UN declaration at World Summit on Social Development in Copenhagen in 1995). Göreli yoksulluk ise gelir eşitsizliği ile ilgilidir ve nüfusun medyan gelirinin sabit bir oranından daha düşük gelire sahip olanların belirli bir yüzdesi olarak tanımlanabilir.

Dünya Bankası verileri küresel ölçekte günlük 1.25 doların altında gelire sahip olanların oranının 1981 yılında \%52 iken 2011 yılında \%17'ye gerilediğini gösterse de yoksulluk sorununun tamamen ortadan kalktığını söylemek doğru olmaz. Günümüzde hala 1 milyardan fazla insanın günlük 1.25 doların altında gelirle yaşıyor olması iktisatçıların yoksulluk konusuna ilgilerini artırmaktadır. Yoksulluğun tespiti ve azaltılması konusundaki politika önerileri bilim insanları kadar politikacıları da yakından ilgilendirmektedir. Eğitim ve sağlık hizmetlerinden yararlanamama, suça yönelme, aile içi şiddet, karakter erozyonu, sosyal dışlanma, çocuk işçiliğindeki artış ve adaletsiz gelir dağılımı yoksulluğun ortaya çıkardığı sonuçlardan sadece bazılarıdır (Odabaşı, 2009). Bu perspektiften bakıldığında yoksulluk tartışılması ve önlem alınması gereken başlıca iktisadi sorunlar arasında yer almaktadır.

Dünyada yoksulluk konusuna atfedilen önem, dinamikleriyle ve farklı boyutlarıyla yoksulluğu inceleyen çalışmaların ekonomi literatüründe ön plana çıkması sonucunu doğurmuştur. Bu çalışmaların güncel ve önemli bir bölümü, yoksulluğa geçiş ve yoksulluktan çıkışı etkileyen faktörleri analiz etmektedir (Adabbo 2000; McKernan ve Ratchliffe 2005; Martin ve Cowell 2006; Valetta 2006; Buddelmeyer ve Verick 2007; Andriopoulou ve Tsakloglou 2011; Polin ve Raitano 2012). İlgili çalışmalar tarafından ulaşılan sonuçlar; eğitim, medeni durum, cinsiyet, istihdam durumu ve biçimi, hane halkı özellikleri, yoksul kalınan döneminin uzunluğu ve gelir durumu gibi faktörlerin yoksulluk geçişleri üzerinde etkili olduğunu ortaya koymaktadır.

Çalışmamızda dünyada yoksulluğu inceleyen literatür dikkate alınarak, Türkiye İstatistik Kurumu (TÜİK) tarafından 2006 yılından beri düzenlenen Gelir ve Yaşam Koşulları Araştırmaları'ndan (GYKA) elde edilen verilerle, 2005-2011 dönemi için Türkiye'de yoksulluğun profilini incelemeyi amaçlamaktayız. Bu amaca uygun olarak ilgili dönemde GYKA kesit verilerinden faydalanarak her yıl için yoksulluk sınırı, yoksulluk oranı ve yoksulluk açığını hesapladıktan sonra hane halkı ve fertlerine ilişkin demografik, ekonomik ve sosyal özellikler çerçevesinde yoksul ve yoksul olmayanların dağılımını 
değerlendirmekteyiz. Daha sonrasında ise bireylerin zaman içerisinde yoksulluk sınırını aşabilme ya da yoksulluk sınırının altına düşebilme olasılıklarını ve bu geçişlerde etkili olan faktörleri incelemekteyiz. Bu amaçla GYKA panel verilerinden faydalanmakta ve 20052011 döneminde hane halklarının yoksulluktan çıkış ve yoksulluğa giriş olasılıklarını iki ayrı probit modelini kullanarak tahmin etmekteyiz. Çalışmamız, gelişmekte olan bir ülke olarak Türkiye için var olan sınırlı literatürden farklı olarak yoksulluk profili ile ilgili daha geniş bir dönemi kapsayan analizler sunmaktadır. Bununla birlikte yoksulluk dinamiklerini açıklamak üzere Türkiye için önem taşıdığı düşünülen, istihdam durumu ve biçimine ilişkin istihdam geçişleri ve sosyal güvenlik sistemine kayıtlılık gibi göstergeler de analizlere dahil edilmiştir. $\mathrm{Bu}$ çerçevede, çalışmamızın 2. ve 3. bölümlerinde Türkiye'deki yoksulluk literatürü ve profili sunulacak, 4. bölümde veri seti ve ampirik analiz sonuçlarına ilişkin açıklamalara yer verilecektir. 5. bölüm ise sonuç ve değerlendirmelere ayrılmıştır.

\section{Türkiye'de Yoksulluk Literatürü}

Türkiye'de yoksulluğa ilişkin literatür incelendiğinde, yoksulluğun yapısal karakterinin daha çok güncel çalışmalar tarafindan ortaya konulduğu görülmektedir. Bunun olası bir nedeni, Şeker ve Jenkins (2013) tarafından da belirtildiği gibi, yoksulluk sınırı ve bundan türetilen yoksulluk oranlarının TÜİK tarafından 2004 yılında ilk kez ilan edilmesi, yoksulluk ve ilgili kavramları tanımlama çabasından öteye geçilerek Türkiye'deki yoksulluk profilini ortaya koyacak biçimde yeniden şekillendirilmesidir. Dolayısıyla çalışmamızın bu bölümünde, 2004 sonrası dönemde Türkiye'de yoksulluğu inceleyen önemli çalışmalardan bahsedeceğiz.

Aran vd. (2010), 2003-2006 döneminde Türkiye'deki yoksulluğu TÜİK tarafından düzenlenen Hane Halkı Bütçe Anketleri ile incelemişlerdir. Çalışmadan elde edilen sonuçlar incelenen dönemde yoksullukla karşı karşıya kalma riskinin kırsal kesimde, çok çocuklu büyük ailelerde, tarımsal işçiler ve eğitim düzeyi düşük bireylerde daha yüksek olduğunu göstermektedir. Çalışma ayıca çocuklar için göreli yoksulluk riskinin arttığını göstererek, çocuk yoksulluğuna dikkat çekmektedir.

Aran vd. (2010) ile aynı veri kaynağını ancak metodoloji olarak tek ve çok değişkenli ayrıştırma yöntemlerini kullanan Şeker ve Jenkins (2013), Türkiye'de 2003-2011 döneminde mutlak yoksulluk oranlarının ciddi bir biçimde düştüğünü ortaya koymaktadır. Bununla birlikte, söz konusu düşüşün 2003-2008 alt döneminde, 2008-2011 alt dönemine göre daha hızlı olduğuna dikkat çekilmektedir. Ayrıştırma sonuçları, yoksullukta her iki dönemde gözlenen düşüşün gelirin yeniden dağılımından ziyade ekonomik büyüme kaynaklı olduğunu ortaya koymaktadır. Bunun yanı sıra, çalışma 2003-2008 döneminde yoksulluğun tüm nüfus grupları için azalırken; 2008-2011 alt döneminde, köyden kente göç, hane halkının fert sayısındaki artış ve hane halklarının daha yaşlı ve az eğitimli bireylerden oluşması gibi yoksulluk artırıcı değişimlere bağlı olarak, azalışın sadece belirli alt gruplara yansıdığını ortaya koymaktadır. 
Avrupa Birliği göreli yoksulluk sınırı tanımını kullanan Güloğlu vd. (2012), Türkiye'de 1994-2006 döneminde yoksulluğun analizi için TÜİK Hane Halkı Bütçe ve Gelir Anketlerinden faydalanmaktadır. Çalışmanın lojistik regresyon sonuçları, eğitim düzeyi, istihdam durumu ve demografik değişkenlerin göreli yoksulluk düzeyini önemli bir biçimde etkilediğini ortaya koymaktadır.

Azevedo ve Atamanov (2014) işgücü piyasaları ve sosyal transferlerdeki gelişmelere bağlı olarak Türkiye'de yoksulluğun azaldığını ve orta sınıfın genişlediğini ortaya koymaktadır. Söz konusu bu gelişimin devam ettirilebilmesi için ise, piyasalara erişime ilişkin olarak cinsiyet ayrımcılığı ile kentsel ve kırsal farkların önüne geçilmesi, kadınların işgücüne katılım oranlarının arttırılması gibi politika önlemlerinin üzerinde durulmaktadır. Türkiye'de yoksulluğu tanımsal istatistikler ile inceleyen bir diğer çalışma olan Yükseler ve Türkan (2007) ise, yoksulluk oranında son dönemde gözlenen düşüşün tüketime dayalı olarak yapılan yoksulluk hesaplarına dayandığından yanıltıcı olduğunu ileri sürmektedir. Bu yanılgıyı gidermek için ise, yoksulluk hesaplamalarının tüketimin yanı sıra gelire de dayandırılması gerektiği vurgulanmaktadır.

Şeker ve Dayığlu (2014), GYKA'yı kullanarak Türkiye için 2005-2008 döneminde yoksulluğun dinamiklerini analiz etmektedir. Çalışmanın sonuçları, nüfusun yaklaşık \%8'inin kalıcı bir biçimde, diğer bir ifadeyle uzun süreli yoksul olduğunu ortaya koymaktadır. Bu gruptaki bireylerin, düşük eğitimli, genç, az sayıda ferdin çalıştığı ailelere sahip olmaları ve ücretsiz aile işçiliği gibi işlerde istihdam edilmeleri nedeniyle kayıt dışı istihdamın da olası birer bileşeni oldukları ileri sürülmektedir. Diğer taraftan, yoksulluktan çıkış oranı $\% 35$, yoksul durumuna geçiş oranı ise yaklaşık $\% 9$ olarak bulunmakta ve bu oranların büyük ölçüde işgücü piyasası dinamikleri tarafindan belirlendiği vurgulanmaktadır. Sonuçlar, sosyal transferlerin yoksulluktan çıkış olasılığını yükseltme veya yoksulluğa geçiş riskini azaltmadaki rolünün, gelişmiş sosyal güvenlik sistemine sahip ekonomilere göre daha sınırlı olduğunu ortaya koymaktadır. Sosyal transferlerin arttırılmasının yoksulluğu azaltmadaki önemine vurgu yapan bir diğer çalışma olan Sarısoy ve Koç (2010), diğer çalışmalardan farklı olarak zaman serisi tekniklerini kullanmaktadır. Çalışmanın ortaya koyduğu sonuçlar kamu sosyal transfer harcamalarının; kadınlara kıyasla erkeklerin, tarım sektöründekilere kıyasla diğer sektörlerde faaliyet gösterenlerin ve ücretliler ile işverenlere kıyasla yevmiye ile çalışanların yoksulluk oranını daha belirgin biçimde azalttığını göstermektedir.

GYKA'yı kullanarak yoksulluğun dinamiklerini ele alan bir diğer çalışmada Gürsel ve Acar (2015), yoksulluğa geçiş ve yoksulluktan çıkışı etkileyen faktörleri incelemektedir. 2008-2011 dönemini analiz eden çalışmanın sonuçları, eğitim seviyesi ile yoksulluğu ilişkilendirmekte; düşük eğitim seviyesinin yoksulluğa girişi hızlandırdığını ileri sürmektedir. Çalışmada eğitim seviyesinin yanı sıra; hane büyüklüğü, çocuk sayısı, çalışan, işsiz ve emekli sayıları, sahip olunan gelirin türü ve kaynağı gibi faktörlerin de yoksulluğa geçişi belirlediği ortaya konulmaktadır. GYKA panel verisini ikili seçim modelleriyle analiz eden Acar ve Başlevent (2014) de, benzer sonuçlara ulaşmaktadır. Çalışmada eğitim süresi, 
ev sahipliği ve gelir artışları ile hanedeki emekli sayısındaki artışın yoksulluktan çıkış olasılığını arttırdığı ileri sürülmektedir. Bununla birlikte; hane büyüklüğü, kayıt dışı çalışanların sayısındaki artışın yoksulluktan çıkış olasılığı üzerindeki etkisinin ise tersi yönde olduğu ortaya konulmaktadır. Çalışmada ayrıca işgücünün miktarı ve gelir türündeki değişikliklerin, istihdam durumuna kıyasla yoksulluk geçişleri üzerinde daha anlamlı etkilere sahip olduğu sonucuna ulaşılmaktadır.

\section{Türkiye'nin Genel Yoksulluk Profili}

Dünya geneline bakıldığında mutlak yoksulluk göstergeleri açısından Türkiye'nin durumunun çok kötü olduğu söylenemez. Aşağıdaki tabloda satın alma gücü paritesi ile günde 1.25 dolardan az gelire sahip olan nüfusun toplam nüfusa oranı verilmiştir. Türkiye'de günde 1.25 doların altında gelire sahip olan nüfus, toplam nüfusun 1990 yılında \%0,6'sını; 2011 yılında ise \%0,1'ini oluşturmaktadır. Dünyada bu oranların en yüksek olduğu bölgeler \%47 ile Sahra altı Afrika’sı ve \%25 ile Güney Asya’dır. Doğu Asya ve Pasifik bölgesinde ise yoksulluk oranında ciddi düşüşler yaşandığı gözlenmektedir.

Tablo: 1

Türkiye ve Seçilmiş Bazı Bölgelerine ait Yoksulluk Oranları*

\begin{tabular}{|l|c|c|}
\hline & $\mathbf{1 9 9 0}$ & $\mathbf{2 0 1 1}$ \\
\hline Doğu Asya ve Pasifik & 57 & 7.9 \\
\hline Avrupa ve Orta Asya & 1.5 & 0.5 \\
\hline Güney Amerika ve Karayipler & 12.2 & 4.6 \\
\hline Orta Doğu ve Kuzey Afrika & 5.8 & 1.7 \\
\hline Güney Asya & 54.1 & 24.5 \\
\hline Sahra altı Afrika & 56.6 & 46.8 \\
\hline Dünya & 36.4 & 14.5 \\
\hline Türkiye & 0.6 & 0.1 \\
\hline
\end{tabular}

Kaynak: <http://povertydata.worldbank.org/poverty/home>, 28.03.2014.

Tablo: 2

Farklı Yöntemler ile Hesaplanmış Fert Yoksulluk Oranları (2002-2013), Türkiye

\begin{tabular}{lcccccccccccc}
\hline Yöntemler & \multicolumn{10}{c}{ Fert yoksulluk oranı (\%) } \\
\cline { 2 - 11 } & $\mathbf{2 0 0 2}$ & $\mathbf{2 0 0 3}$ & $\mathbf{2 0 0 4}$ & $\mathbf{2 0 0 5}$ & $\mathbf{2 0 0 6}$ & $\mathbf{2 0 0 7}$ & $\mathbf{2 0 0 8}$ & $\mathbf{2 0 0 9}$ & $\mathbf{2 0 1 0}$ & $\mathbf{2 0 1 1}$ & $\mathbf{2 0 1 2}$ & $\mathbf{2 0 1 3}$ \\
\hline $\begin{array}{l}\text { Kiși bașı günlük } \\
\mathbf{2 , 1 5} \text { \$'ın altı } \\
\text { Kiși bașı günlük } \\
\mathbf{4 , 3} \text { \$'ın altı }\end{array}$ & 3,04 & 2,39 & 2,49 & 1,55 & 1,41 & 0,52 & 0,47 & 0,22 & 0,21 & 0,14 & - & - \\
\hline
\end{tabular}

Kaynak: TÜIKK-Haber Bulteni / Yoksulluk Çalışması - 2013.

Tablo: 2 günlük 2.15 ve 4.30 doların altında gelire sahip olan fertlerin oranını göstermektedir. Bir başka mutlak yoksulluk oranı olarak nitelendirilebilecek bu yoksulluk verileri Türkiye'de yoksulluğun 2002 yılından 2013 yılına gelindiğinde azaldığını 
göstermektedir. Günlük geliri 2.15 doların altında olan fertlerin oranı 2002 yılında $\% 3,4$ iken, bu oran 2011 yılında $\% 0.14$ 'e gerilemiştir. Benzer şekilde kişi başına günlük 4.30 doların altında gelire sahip olanların oranı da hızla gerileme göstermiştir. 2002 yılında toplam nüfusun \%30'undan fazlası günlük olarak 4.30 dolardan daha az gelir elde ederken, 2013 yılında toplam nüfusun sadece \%0.06's1 günlük 4.30 dolar sinırının altında gelire sahiptir.

Mutlak yoksulluk, giriş kısmında da belirtildiği gibi, kişinin asgari kalori düzeyindeki beslenmeyi sağlayacak gelire sahip olamaması olarak tanımlanırken, göreli yoksulluk bireyin beslenme ihtiyacının yanı sıra eğitim, sağlık, bilgi edinme gibi kültürel ve toplumsal açıdan tüketimi zorunlu olan malları da kapsamaktadır. Dolayısı ile göreli yoksulluk sınırı toplumdaki genel yaşam düzeyini yansıtması ve içerisindeki eşitsizliği göstermesi açısından mutlak yoksulluğa göre daha önemlidir (Gürses, 2007).

Bir diğer yoksulluk ölçütü olarak yoksulluk açığı yoksulların ortalama gelirinin yoksulluk sınırından ne kadar farklılaştığını göstermektedir. TÜİK'e göre, 2005 yılından 2012 yılında gelindiğinde Türkiye'de yoksulluk sınırı yükselmiş, yoksul sayısı, yoksulluk oranı ve yoksulluk açığı düşüş göstermiştir. Bu iyileşmelere rağmen 2012 yılında Türkiye'de halen 11 milyon yoksul insanın varlığı düşündürücüdür. Öte yandan yoksulluk açığının yüksek olması yoksullar arasındaki gelir eşitsizliğinin de oldukça yüksek olduğuna işaret etmektedir.

\section{Grafik: 1}

Türkiye ve Çeşitli Ülkelerde Yoksulluk Oranı ve Yoksulluk Açı̆̆ı, 2010

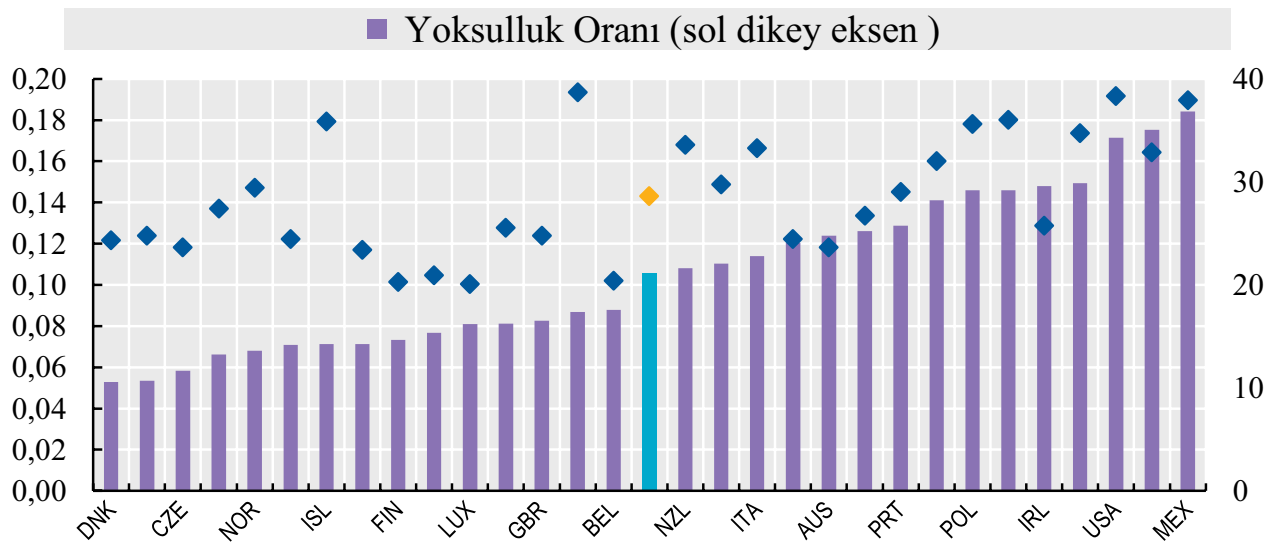

Kaynak: OECD Factbook 2010: Economic, Environmental and Social Statistics. 
Grafik: 1 OECD'den elde edilmiş yoksulluk oranları ve yoksulluk açığı verilerini göstermekte dolayısıyla Türkiye için bir karşılaştırma yapma imkânı sunmaktadır. \%32.8 yoksulluk açığı ile Türkiye; İtalya, Yeni Zelanda, Japonya, Polonya, İzlanda, Kore, Meksika, ABD ve İsviçre'den iyi durumdadır. Yoksulluk oranları göz önüne alındığında ise 30 ülke arasından Türkiye'nin durumunun sadece Meksika'dan iyi olduğunu belirtmek gerekir.

Beşeri kalkınma endeksi, içerdiği eğitim, sağlık ve uzun yaşam verileri ile yoksulluk literatüründe kullanılan bir başka önemli göstergedir. Türkiye 2005 yılında 0.68'lik endeks değeri ile 88. sırada yer alırken, 2012 yılında 0.72 endeks değeri ile 90. sıraya gerilemiştir. 2012 yılındaki 0.72 'lik endeks değeri, en düşük endeks değerine sahip iki ülke olan Bulgaristan (0.78) ve Romanya (0.78) dâhil tüm Avrupa Birliği üyesi ülkelerden daha düşüktür (UN, 2015).

Bu bölümde incelenen Türkiye'nin yoksulluk göstergeleri, ülkede yoksulluğun boyutu hakkında genel bir fikir verse de, yoksulluktan hangi demografik grupların daha çok etkilendiği, yoksulluğa giriş ve yoksulluktan çıkış olasılıkları ile bu olasılıkların belirleyicileri için daha detaylı analizlere ihtiyaç vardır. İzleyen bölümde TÜİK tarafından yapılan GYKA verileri kullanılarak 2005-2011 dönemi için detaylı yoksulluk analizleri yer alacaktır.

\section{Veri Seti ve Bulgular}

Bu çalışmanın amacı TÜİK tarafından düzenlenen GYKA'dan elde edilen verilerle 2005-2011 döneminde Türkiye'de yoksulluğun profilini incelemektir. Çalışma boyunca, literatürde sıklıkla kullanılan göreli yoksulluk ölçütüne dayanarak yoksulluğu çeşitli birey ve hane halkı özelliklerine göre irdelemekte, yoksulluktan çıkışta ve yoksul olma durumuna geçişte söz konusu faktörlerin ne yönde ve ne kadar etkili olduğunu sorgulamaktayı.

GYKA'ya ilişkin anketler, gelir, yoksulluk, sosyal dışlanma ve yaşam koşulları ile ilgili detaylı bilgileri elde etmek amacıyla, Avrupa Birliği İstatistik Ofisi (EUROSTAT) tarafindan talep edilen hedef değişkenler doğrultusunda TÜİK tarafından 2006 yılından beri düzenlenmektedir. Anket uygulamasının yüz yüze görüşme tekniği ile yapıldığı araştırmalarda, haneler nihai örnekleme birimleri olarak belirlenmektedir. Türkiye Cumhuriyeti sınırları içerisinde kalan bütün yerleşim birimleri örnekleme seçimi kapsamında yer almakta ve bu sınırlar içerisinde yer alan tüm ailelerin üyeleri bu kapsama dâhil edilmektedir. Ancak huzur evlerinde, hapishanelerde, askeri kışlalarda, hastanelerde, otellerde ve çocuk bakım merkezlerinde yaşayanlar ile göçmen nüfus araştırma kapsamının dışında tutulmaktadır. GYKA; cinsiyet, sağlık durumu, yaş, eğitim düzeyi (7 eğitim seviyesi 
olarak kodlanmış ${ }^{1}$ ) gibi bireysel özelliklerin yanı sıra işgücü piyasasına ait kayıt dışılık, firma büyüklüğü ve sektörel (NACE Rev.1.1) sınıflandırmalarla hane halkı ve bireylere ait gelir türleri ve konut sahipliği gibi yaşam koşullarının parasal belirleyicileri hakkında detaylı bilgiler içermektedir.

GYKA'da rotasyonel tasarım kullanılmaktadır. Bu yönteme göre, hanelerin bir kısmı bir yıldan öteki yıla kadar örneklem çerçevesinde kalırken, her yıl örneklem çerçevesine yeni haneler dâhil edilmektedir. Bu yaklaşım çerçevesinde örneklem sayısının \%75'i panel çerçevesinde bırakılırken, \%25'i her y1l değişmektedir. Bu şekilde, panel uygulaması, temel nüfusu temsil eden temel örneklem seçimi ile başlamakta ve bireyler, gözlemleme uygulamasının kuralları doğrultusunda dört yıl boyunca izlenmektedirler.

$\mathrm{Bu}$ çalışma boyunca yoksulluğun birey ve hane özelliklerini ele alan genel profilini sunmak üzere yapılan analizler 2006-2012 zaman periyodundaki 7 ayrı kesit veri setine dayanmakta olup, yoksullukla ilgili dinamik analizlerimiz 2006-2009 ve 2009-2012 yıllarını kapsayan iki ayrı dengelenmemiş panel veri setine dayanmaktadır. GYKA'daki gelire ilişkin veriler bir önceki referans yılını yansıttı̆̆ından parasal gelire dayanarak yaptığımız yoksulluk analizleri 2005-2011 yıllarını kapsamaktadır. Yoksullukla ilgili analizlere geçmeden önce bireyleri "yoksul değil” ve "yoksul” olarak tanımlamak üzere kullandığımız parasal ölçüt, Avrupa Birliği Komisyonu'nun önerdiği, fert başına eşdeğer kullanılabilir hane halk1 medyan gelirinin yüzde 60'1 olarak kabul edilen göreli yoksulluk sınırıdır. Hane halkı kullanılabilir gelirini ${ }^{2}$ kullanarak eşdeğer hane halkı (fert) gelirini ${ }^{3}$ hesapladıktan sonra göreli yoksulluk sınırının altında kalan bireyleri yoksul olarak tanımlamaktayız. Eşdeğer hane halkı gelirini hesaplamak için OECD tarafından kullanılan ölçekten faydalanmaktayız. Buna göre hanedeki ilk yetişkin (referans fert-hane halkı reisi ${ }^{4}$ ) $1 ; 14$ yaşın üzerindeki diğer yetişkin bireyler 0.5 ; 15 yaşın altındaki bireyler ise çocuk olarak tanımlanmış ve 0.3 ağırlığını almıştır. Böylelikle hane büyüklüğünün kaç eşdeğer ferde denk geldiği bulunmuş ve eşdeğer hane halkı büyüklükleri hesaplanmıştır. Daha sonra her bir hanenin toplam yıllık kullanılabilir geliri ${ }^{5}$ eşdeğer hane halkı büyüklüğüne bölünerek hane

1 Okur-yazar olmayan; okur-yazar olup bir okul bitirmeyen; ilkokul mezunu; ortaokul, mesleki ortaokul ve ilköğretim mezunu; genel lise mezunu; mesleki veya teknik lise mezunu; yüksekokul, fakülte ve üzeri.

2 Hane halkı kullanılabilir geliri, hanedeki bütün fertlerin bireysel gelirleri (nakdi ve ayni ücret-maaş-müteşebbis gelirleri, menkul ve gayrimenkul klymet gelirleri, transfer gelirleri) toplandıktan sonra bu toplamdan düzenli ödenen vergilerin ve haneden diğer hane ya da hane dışı diğer fertlere yapılan transferlerin düşülmesiyle elde edilmektedir.

3 Eşdeğer hane halkı (fert) geliri hanelerin yetişkin ve çocuk sayısı ile bunların bileşimini dikkate almak üzere hesaplanır. Böylelikle, hane halklarının gida ve giysi gibi bireysel tüketimlerinin yanı sıra konut harcamalart gibi ortak tüketimleri de hesaba katılmakta, farklı büyüklüğe ve bileşime sahip hanelere ait bireylerin gelirlerini hesaplamak için hane gelirini toplam fert sayısına bölmek yerine gelir, eşdeğer fert büyüklüğüne bölünmektedir. Ölçeklemeyle ilgili daha ayrıntılı bilgi için bkz. Atkinson (1975).

4 Hane halkının sosyo-ekonomik durumu ve hanede yaşayan tüm fertlerin kişisel özellikleri hakkında en doğru bilgiye sahip, hanenin yönetim veya geçiminden sorumlu yetişkin hane halkı üyesidir (TÜIK, GYKA, 2012).

5 Bundan önce yıllık gelirler tüketici fiyat endeksi kullanılarak reel gelire çevrilmiştir. 
halkı eşdeğer geliri hesaplanmıştır. Göreli yoksulluk sınırları 2006-2012 yıllarındaki kesit verilerden medyan eşdeğer hane halkı kullanılabilir gelirinin yüzde 60'1 hesaplanarak elde edilmiştir ${ }^{6}$.

Tablo: 3

Göreli Yoksulluk Sınırına Göre Türkiye’nin Genel Yoksulluk Profili (2005-2011)

\begin{tabular}{lccccccc}
\hline \hline & $\mathbf{2 0 0 5}$ & $\mathbf{2 0 0 6}$ & $\mathbf{2 0 0 7}$ & $\mathbf{2 0 0 8}$ & $\mathbf{2 0 0 9}$ & $\mathbf{2 0 1 0}$ & $\mathbf{2 0 1 1}$ \\
\hline Yoksulluk Sinırı & 2217 & 2558 & 2473 & 2471 & 2554 & 2545 & 2620 \\
Yoksulluk Oranı & 25.79 & 24.32 & 24.14 & 25.39 & 24.14 & 23.82 & 24.35 \\
Yoksulluk Açıı̆ & 33.8 & 28.2 & 27.9 & 30.1 & 30.0 & 30.7 & 29.6 \\
\hline \hline
\end{tabular}

Kaynak: Yazarların GYKA kesit verilerini kullanarak yaptıkları kendi hesaplamalarıdır.

Tablo: 3'de GYKA kesit verilerinden elde edilen yoksulluk oranları ve yoksulluk açığı sunulmaktadır. Yoksulluk oranı ya da literatürde sıklıkla kullanılan ismiyle kafa sayım endeksi (headcount index) en temel yoksulluk göstergesi olup yoksulluk sınırının altında kalan kişilerin toplam nüfusa oranı şeklinde hesaplanmaktadır. Buna göre 2006-2012 kesit verilerindeki örneklemlerden yola çıkarak hesapladığımız göreli yoksulluk oranları 2005 yılından küresel ekonomik krizin yaşandığı 2008 yılına kadar azalan bir seyir izlemiş, 2008 'de artmış daha sonra tekrar düșme eğilimine girmiștir. Söz konusu dönemde yoksulluk oranında düşmeye yol açan faktörlerden biri ortalama gelirdeki yükselmedir ${ }^{7}$. Tablo: 4'de de görüldüğü gibi eșdeğer hane halkı medyan gelirinin yüzde 60'1 olarak hesaplanan yoksulluk sınırı 2005 yılından 2011 yılına kadar \%18.2 artmıştır. Yoksulluktaki gerilemenin bir diğer önemli bileşeni gelir eşitsizliğindeki azalmadır. Bilindiği üzere mutlak yoksulluk yaklaşımının aksine toplumda yoksulluğun zaten var olduğu varsayımından hareket eden göreli yoksulluk ölçümleri bir eşitsizlik ölçütü olarak da değerlendirilebilmektedir. Göreli yoksulluğun azaltılabilmesinin bir yolu da eşit bir gelir dağılımının sağlanmasıdır (Bkz. Şenses, 2009). 2005-2011 yılları arasında, Türkiye'de gelir eşitsizliği ${ }^{8}$ göreli yoksulluk oranları ile paralel bir seyir izlemektedir. Gini katsayısı 2011 'de 0.40 seviyesine gerilemiştir. İlgili dönemin geneline bakıldığında Gini katsayısındaki düşme eğilimine rağmen bu katsayının değeri gelişmiş ülkelerinkine oranla hala oldukça yüksektir. Türkiye'nin gelir eşitsizliği bakımından, sadece Meksika'dan daha iyi konumda olması, ilgili dönemde gelir

6 Göreli yoksulluk sınırlarını eșdeğer kullanılabilir hane halkı medyan gelirinin \%40'ını, \%50'sini ve \%70'ini esas alarak da hesaplanabilmektedir. Bu çalışmada Avrupa Birliği 'nin kullandığı sınır baz alınmaktadır.

7 Benzer biçimde 2008 yllında yoksulluk oranında yaşanan artışın önemli bir nedeni büyümede küresel ekonomik krizin yarattığl önemli gerilemedir. 2006 yılında \%6.9 olarak gerçekleşen GSYH büyümesi 2008 yılında 0.7'ye düșmüs 2009 yılında ise -4.7 olarak gerçekleșmiștir.

8 Eşitsizlik ölçütü olarak TÜIK'in hesapladığı Gini katsayıları referans alınmıştır. 
eşitsizliğindeki sınırlı azalmanın, yoksulluktaki düşüşe yaptığı katkının ortalama gelir artışına oranla çok daha sınırlı olduğuna işaret etmektedir ${ }^{9}$.

Tablo: 3'de sunulan yoksulluk açı̆̆ı endeksi, toplumdaki yoksulluğun derinliğiyle ilgili bilgi vermektedir. Bir başka deyişle, yoksulluk açığı var olan yoksulluk boyutunun yoksulluk sınırının bir yüzdesi olarak ifade edilmesine ve yoksulların ortalama gelirinin yoksulluk sınırından ne kadar farklılaştığının görülmesine yaramaktadır. Yoksulluk açı̆̆ı, tüm yoksul bireylerin yoksulluk sinırından uzaklıkları toplamının yoksul sayısına bölünmesiyle bulunur ${ }^{10}$. Yoksulluk açığı 2005-2007 döneminde yoksulluk oranındaki düşüşe paralel olarak düşmekte, 2008 yılında bir miktar yükseldikten sonra tekrar düşme eğilimine girmektedir. Yoksulluk açığı 2005 yılında 33.8 iken 2008 yılında 30.1 olarak gerçekleşmiştir. Buna göre, yoksulluk oranındaki düşüşün yanı sıra yoksul bireylerin yoksulluk sınırına uzaklığı da azalmaktadır. Yoksulluk açığı oranındaki azalma yoksul birey sayısının azalmasına bağlı olabileceği gibi yoksul bireyleri gelirleri ile yoksulluk sınırı arasındaki farkın azalmasına bağlı olarak da düşebilir. 2010 yılına gelindiğinde yoksulluk oranındaki düşüşün tersine yoksulluk açığında bir artış görülmektedir. Buna göre, 2009 yılındaki hızlı küçülmeye paralel olarak yoksulluk sınırında meydana gelen düşüşle birlikte yoksul bireylerin gelirleri ile yoksulluk sınırı arasındaki fark küçülmüş ancak yoksul birey sayısı büyümedeki hızlı gerilemeden dolayı mutlak olarak artmıştır ${ }^{11}$.

Tablo: 3'de GYKA verilerinden faydalanarak kendi hesapladığımız reel yoksulluk sınırlarını temel alarak elde ettiğimiz yoksulluk oranları ve endeksleri Türkiye'de 2005-2011 döneminde yoksulluğa ait genel bir çerçeve çizmektedir. Türkiye gibi toplumda yaşayan bireyler arasında yüksek oranda gelir ve firsat eşitsizliğinin bulunduğu bir ülkede, yoksullukla ilgili yapılacak kapsamlı bir analiz, yoksulluk profilinin yoksulluğun temel belirleyicileri olan bireylere ilişkin demografik ve sosyal özelliklerin de hesaba katılarak sunulmasını gerektirir. Bu sebeple çalışmamızın bir sonraki aşamasında, yoksulluğun fert ve haneye ilişkin çeşitli sosyo-ekonomik değişkenlere göre dağılımını ele almaktayız. Yoksulluğu belirleyen temel faktörler genel olarak, bölgesel ve toplumsal faktörler ile hane ve fertlere ilişkin faktörler olarak sınıflandırılmakla birlikte (Bkz. Dünya Bankası, 2005); bu çalışmada üzerinde durulan birey ve hane halkına ilişkin özellikler sırasıyla yaş, cinsiyet, eğitim durumu, istihdam durumu, sosyal güvenlik sistemine kayıtlılık, sağlık durumu, hanenin büyüklüğü, hanedeki çocuk sayısı ve hanenin gelir edinme durumudur.

9 Şeker ve Jenkins (2013) 2003-2008 döneminde yoksullukta yaşanan düşüşün \%68'inin gelir artışılndan, $\% 32$ 'isinin ise gelir eşitsizliğindeki iyileşmeden kaynaklandiğını göstermektedirler; Bkz. Güven vd. (2014).

10 TÜIK, Eurostat'’ takip ederek yoksulluk açığı oranı için farklı bir hesaplama tekniği kullanmaktadırlar. TÜIK her bir yoksul bireyin yoksulluk sinırından uzaklığın hesaplamak yerine yoksul bireylerin medyan geliri ile yoksulluk sinırı arasındaki uzaklığı dikkate almaktadır.

11 Yoksulluk açığı endeksi, aynı zamanda, yoksul bireylerin gelirinin yoksulluk sınırına çekilebilmesi için gerekli transfer miktartyla ilgili de bilgi vermektedir. Dolaylsiyla, GSYH'de meydana gelen düşüşle birlikte 2009 yılında yoksulluğun giderilmesi için yapılabilecek transfer maliyetinin de arttığını söylemek mümkündür. 
Tablo: 4

Hane halkı ve Hane halkı Reisinin Özelliklerine göre Türkiye’nin Yoksulluk Profili

\begin{tabular}{|c|c|c|c|c|c|c|c|c|c|c|c|c|c|c|}
\hline & \multicolumn{2}{|c|}{2005} & \multicolumn{2}{|c|}{2006} & \multicolumn{2}{|c|}{2007} & \multicolumn{2}{|c|}{2008} & \multicolumn{2}{|c|}{2009} & \multicolumn{2}{|c|}{2010} & \multicolumn{2}{|c|}{2011} \\
\hline & $\begin{array}{l}\text { Yoksul } \\
\text { Değil }\end{array}$ & Yoksul & $\begin{array}{l}\text { Yoksul } \\
\text { Değil }\end{array}$ & Yoksul & $\begin{array}{l}\text { Yoksul } \\
\text { Değil }\end{array}$ & Yoksul & $\begin{array}{l}\text { Yoksul } \\
\text { Değil }\end{array}$ & Yoksul & $\begin{array}{c}\text { Yoksul } \\
\text { Değil }\end{array}$ & Yoksul & $\begin{array}{l}\text { Yoksul } \\
\text { Değil }\end{array}$ & Yoksul & $\begin{array}{c}\text { Yoksul } \\
\text { Değil }\end{array}$ & Yoksul \\
\hline \multicolumn{15}{|l|}{ Yaș (hane_referans) } \\
\hline $15-24$ & 1.57 & 1.41 & 2.52 & 2.76 & 2.99 & 2.90 & 2.97 & 2.83 & 2.79 & 2.67 & 2.52 & 2.20 & 2.27 & 2.41 \\
\hline $25-34$ & 16.89 & 23.04 & 16.02 & 21.21 & 17.87 & 20.26 & 18.30 & 18.90 & 16.95 & 18.74 & 17.16 & 18.76 & 16.47 & 16.11 \\
\hline $35-44$ & 24.48 & 30.07 & 23.90 & 30.75 & 23.47 & 32.79 & 22.84 & 31.31 & 23.36 & 31.09 & 22.54 & 31.10 & 21.85 & 29.58 \\
\hline $45-54$ & 23.77 & 20.23 & 24.50 & 20.53 & 24.25 & 20.67 & 23.91 & 20.31 & 23.80 & 20.79 & 23.62 & 21.08 & 23.41 & 22.05 \\
\hline $55-64$ & 16.89 & 11.62 & 16.57 & 10.94 & 15.66 & 11.61 & 16.07 & 12.23 & 16.42 & 12.26 & 17.16 & 11.72 & 18.31 & 11.58 \\
\hline $64+$ & 16.39 & 13.63 & 16.49 & 13.81 & 15.76 & 11.76 & 15.92 & 14.42 & 16.68 & 14.45 & 17.00 & 15.14 & 17.69 & 18.26 \\
\hline \multicolumn{15}{|l|}{ Cinsiyet (hane-referans) } \\
\hline Kadın & 12.77 & 11.47 & 14.10 & 11.82 & 14.27 & 11.91 & 15.83 & 13.83 & 15.84 & 13.69 & 15.64 & 14.51 & 16.32 & 15.33 \\
\hline Erkek & 87.23 & 88.53 & 85.90 & 88.18 & 85.73 & 88.09 & 84.17 & 86.17 & 84.16 & 86.31 & 84.36 & 85.49 & 83.68 & 84.67 \\
\hline \multicolumn{15}{|l|}{ Eğitim (hane-referans) } \\
\hline $\begin{array}{l}\text { Okuryazar olmayan / } \\
\text { bir diplomaya sahip olmayanlar }\end{array}$ & 14.67 & 34.05 & 14.85 & 35.26 & 13.06 & 34.03 & 12.25 & 33.28 & 17.27 & 43.41 & 13.00 & 34.65 & 13.02 & 34.74 \\
\hline $\begin{array}{l}\text { İkokul } \\
\text { illay ana }\end{array}$ & 47.59 & 53.35 & 47.55 & 53.19 & 46.04 & 52.68 & 44.48 & 52.44 & 43.31 & 51.89 & 43.52 & 50.31 & 42.86 & 50.62 \\
\hline Ortaokul & 10.35 & 6.58 & 10.80 & 6.69 & 11.06 & 6.64 & 10.83 & 6.80 & 10.40 & 7.30 & 10.76 & 8.03 & 10.77 & 8.02 \\
\hline Genel Lise & 8.52 & 3.43 & 8.37 & 3.35 & 9.43 & 3.63 & 9.40 & 3.06 & 9.34 & 3.20 & 8.79 & 3.78 & 8.27 & 3.65 \\
\hline Meslek Lisesi & 7.63 & 2.17 & 7.70 & 2.09 & 8.44 & 2.61 & 9.57 & 1.96 & 9.84 & 2.58 & 9.30 & 2.48 & 9.62 & 2.09 \\
\hline Yüksek Öğrenim & 11.23 & 0.41 & 11.43 & 0.42 & 11.97 & 0.41 & 13.00 & 0.59 & 9.84 & 0.62 & 14.63 & 0.75 & 15.46 & 0.88 \\
\hline \multicolumn{15}{|l|}{ İstihdam durumu (hane-referans) } \\
\hline Çalışıor & 65.08 & 63.58 & 64.63 & 62.99 & 65.47 & 66.65 & 63.79 & 62.57 & 64.13 & 63.42 & 43.86 & 36.81 & 43.01 & 36.01 \\
\hline Emekli & 19.49 & 2.34 & 20.12 & 2.97 & 19.56 & 2.44 & 19.40 & 3.24 & 19.87 & 3.15 & 2.12 & 9.63 & 1.77 & 8.09 \\
\hline İşsiz & 2.00 & 8.57 & 1.96 & 9.01 & 2.17 & 9.11 & 3.15 & 10.91 & 2.31 & 9.73 & 19.34 & 22.30 & 19.84 & 22.44 \\
\hline İşgücüne katılmıyor & 13.42 & 25.51 & 13.28 & 25.04 & 12.80 & 21.79 & 13.66 & 23.28 & 13.69 & 23.70 & 34.67 & 31.26 & 35.38 & 33.46 \\
\hline \multicolumn{15}{|l|}{ SGK'ya kayttllik (hane-referans) } \\
\hline Kayitlı & 58.25 & 18.19 & 60.24 & 20.54 & 66.01 & 26.18 & 63.81 & 23.57 & 65.52 & 27.64 & 67.61 & 31.16 & 69.37 & 35.49 \\
\hline Kayıtlı değil & 41.75 & 81.81 & 39.76 & 74.46 & 33.99 & 73.82 & 36.19 & 76.43 & 34.48 & 72.36 & 32.39 & 68.84 & 30.63 & 64.51 \\
\hline $\begin{array}{c}\text { Hane eşdeğer bü̈yüklü̆̆̈̈̈ } \\
\text { (ortalama) }\end{array}$ & 2.13 & 2.66 & 2.13 & 2.74 & 2.12 & 2.75 & 2.08 & 2.71 & 2.06 & 2.70 & 2.06 & 2.72 & 2.05 & 2.69 \\
\hline Hane çocuk sayıst & 0.89 & 2.13 & 0.88 & 2.24 & 0.88 & 2.21 & 0.84 & 2.11 & 0.81 & 2.06 & 0.83 & 2.12 & 0.80 & 2.05 \\
\hline \multicolumn{15}{|l|}{$\begin{array}{c}\begin{array}{c}\text { Kronik-müzmin hastalik } \\
\text { (hane-referans) }\end{array} \\
\end{array}$} \\
\hline Var & 35.15 & 39.51 & 34.69 & 38.81 & 34.82 & 38.68 & 37.03 & 41.40 & 36.51 & 63.49 & 37.83 & 43.04 & 38.45 & 42.43 \\
\hline Yok & 64.85 & 60.49 & 65.31 & 61.19 & 65.18 & 61.32 & 62.97 & 58.60 & 41.53 & 58.47 & 62.17 & 56.96 & 61.55 & 57.57 \\
\hline \multicolumn{15}{|l|}{ Hanenin gelir tipi } \\
\hline Hanede yalnızca emek geliri sahibi & 29.05 & 38.57 & 31.26 & 32.38 & 38.39 & 33.20 & 37.39 & 31.43 & 35.28 & 26.53 & 38.75 & 28.98 & 45.01 & 30.51 \\
\hline Kira+Menkul kıymet geliri sahibi & 57.93 & 23.69 & 57.98 & 34.72 & 49.00 & 27.55 & 50.04 & 25.74 & 51.04 & 26.80 & 46.84 & 24.50 & 39.65 & 16.83 \\
\hline Hanede sosyal transfer geliri sahibi & 6.71 & 40.64 & 7.81 & 44.14 & 8.89 & 49.24 & 9.57 & 52.17 & 11.46 & 56.08 & 10.52 & 56.31 & 9.25 & 56.29 \\
\hline \multicolumn{15}{|l|}{ Sektör (hane-referans) } \\
\hline Tarım & 22.46 & 47.94 & 21.97 & 46.15 & 18.94 & 41.43 & 19.30 & 45.77 & 18.75 & 43.02 & 18.59 & 38.81 & 18.36 & 39.91 \\
\hline Sanayi & 18.00 & 10.16 & 18.30 & 8.76 & 19.96 & 9.71 & 18.22 & 9.53 & 18.08 & 11.90 & 17.65 & 12.29 & 17.93 & 11.47 \\
\hline Hizmet & 59.54 & 41.90 & 59.73 & 45.09 & 61.09 & 48.86 & 62.49 & 44.70 & 63.17 & 45.08 & 63.76 & 48.49 & 63.71 & 48.61 \\
\hline Gözlem Sayıs1 & 10920.00 & 10920.00 & 10796.00 & 10796.00 & 11222.00 & 11222.00 & 11870.00 & 11870.00 & 12106.00 & 12106.00 & 15025.00 & 15025.00 & 17562.00 & 17562.00 \\
\hline
\end{tabular}

Kaynak: Yazarlarm GYKA kesit verilerini kullanarak yaptikları kendi hesaplamalarıdır. 
Tablo: 4'de yoksulluğa ilişkin detaylı analizlerde haneye ve hane reisine ${ }^{12}$ ilişkin (yaş, cinsiyet, istihdam ve sağlık durumu) özellikler üzerinde durulmaktadır. Buna göre, yoksul olmayan ve yoksul hane halklarının hane reisinin yaş gruplarına göre dağılımına bakıldığında, çalışan nüfusu temsil eden 15-64 yaş grubunun yoksul hane halkları içindeki payının yoksul olmayan hane halklarına göre yüksek olduğu görülmektedir. Buna göre, yoksul olmayan hane halklarında faaliyet geliri elde edebilecek hane reislerinin oranının yoksul olanlara göre daha yüksek olduğu söylenebilir. Bununla birlikte 64 yaş üstü yaşlı hane reislerinin yoksul olmayan nüfus içerisindeki payı yoksul nüfusa oranla yüksektir. Dahası, 44 yaşın üzerindeki hane reislerinin yoksul olmayan hane halkları içerisindeki payının yoksul olanlara göre daha yüksek olduğu görülmektedir. Buna göre ileri yaşlardaki emeklilik ve tasarruf gelirlerinin yaşlı hane reisiyle yaşayan hane halklarını yoksulluk riskine karşı koruduğu söylenebilir. Öte yandan yoksul hane halklarının, yoksul olmayanlara oranla eşdeğer büyüklüğünün daha yüksek ve çocuk sayısının daha fazla olması yoksul nüfusun daha kalabalık ailelerde yaşadığını ve bu ailelerin daha fazla bağımlı nüfus içerdiğini göstermektedir ${ }^{13}$. Tablo: 4'de yoksul olmayan ve yoksul haneler içerisinde kadın ve erkek hane reislerinin dağılımı da sunulmaktadır. Buna göre hane halkı reisinin kadın olması beklentinin aksine yoksulluk riskini azaltmaktadır.

Tablo: 4'e göre, eğitim durumu bakımından yoksul ve yoksul olmayan hane halkları arasında anlamlı bir fark vardır. Hane reisinin eğitim seviyesi ile yoksulluk arasındaki negatif yönlü ilişki açık şekilde görülmektedir. Örneğin, 2005 yılında yoksul nüfusta ortaokul ve altı mezun durumundaki hane reisiyle yaşayan hanelerin oranı yaklaşık \%94 iken yoksul olmayan nüfusta bu oran \%72'lerde kalmaktadır. Aynı şekilde yükseköğrenim mezunu hane reisleri arasında da yoksul olmayan ve yoksul hane halkları arasında belirgin bir fark vardır (\%11.23'e \%0.41). Yoksul olmayan nüfustaki hane reislerinin eğitim düzeyinin yoksul olanlara göre yüksek olduğu açık iken, eğitim düzeyinin artmasının yoksulluk riskini azalttığı ve aynı zamanda yoksulluğun artmasının da bireylerin eğitime erişimini kısıtlayarak eğitim düzeyinin düşmesine neden olduğu söylenebilir.

Tablo: 4'de sunulan bir diğer bulgu yoksul ve yoksul olmayan nüfusta hane reislerinin istihdam durumuyla ilgilidir. Çalışan hane reisi oranının yoksul olmayan hanelerde yoksul olanlara göre daha yüksek olması beklenen bir sonuç iken bu oranın yoksul ve yoksul olmayan haneler arasında çok da fazla farklılaşmaması yoksulluğun istihdam durumundan çok eğitim seviyesi gibi yapısal özelliklerden daha fazla etkilendiğine işaret

12 Hane halkı reisi 15 yaş ve üzerindedir.

13 Aran vd. (2010) Türkiye'de yoksulluk oranlarındaki azalmaya yoksulluğun daha kalabalık hanelerde yoğunlaşmasının eşlik ettiğini göstermişlerdir. 
etmektedir14. Öte yandan emekli oranının yoksul olmayan hanelerde daha yüksek olması sabit emeklilik transferlerinin yoksulluk riskini azaltıcı etki yaptığını göstermektedir.

Tablo: 4'de yoksul ve yoksul olmayan hane halklarının gelir kaynakları da ele alınmaktadır. Buna göre, yalnızca emek geliri sahibi olmak 2005 ve 2006 yıllarında yoksul aileler için daha belirgin bir durum iken sonraki dönemde durum tam tersidir ${ }^{15}$. Bu durum sosyal transfer yapılan yoksul ailelerin sayısındaki artışla açıklanabilir. Nitekim sosyal transfer geliri sahipliği oranı yoksul hanelerde 2006 yılından 2011 yılına kadar yüzde 28 oranında artmıştır ${ }^{16}$. Bununla birlikte farazi kira geliri sahipliği de yoksul aileler için önemli bir gelir kaynağıdır ve bu durum 2006 yılından sonra daha belirginleşmiştir ${ }^{17}$. Yoksul olmayan hane halklarında, menkul ve gayrimenkul kıymet geliri sahipliği oranı yoksul hanelere göre daha yüksektir.

Yoksul ve yoksul olmayan hane halklarının istihdam durumuna sosyal güvenlik sistemine kayıtlılık ve kayıt dışılık ayrımında bakıldığında, 2006-2011 döneminde yoksul hane reislerinin yaklaşık \% 73 'ünün sigortasız olarak istihdam edildiği görülmektedir. Aynı oran yoksul olmayan nüfusta çok daha düşük olup yoksul olanlara göre daha eğitimli olan yoksul olmayan hane reislerinin sigortalı işlerde çalışma olasılığının daha yüksek olmasına da işaret etmektedir ${ }^{18}$. Bununla birlikte kayıt dışı işgücü piyasası, işsiz ve çalışmaya ihtiyacı olan yoksul fertlerin istihdam edildiği bir yapı sergilemektedir.

Türkiye'de yoksulluğun profili ile ilgili olarak buraya kadar sunulan bulgular GYKA'nın yatay kesit verilerinden hesaplanmıştır. Bireyler zaman içerisinde gelir dağılımının farklı noktalarına doğru hareket edebilmekte ve göreli olarak yoksul iken yoksulluk eşiğini aşabilmekte ya da yoksul değilken yoksulluk sınırının altına düşebilmektedirler. Bireylerin bu hareketliliği ve bunda etkili olan faktörlerin incelenmesi politika tasarımları ve hedefleri açısından oldukça önemlidir. Bu nedenle hane halklarının olası hareketliliğini dikkate almak ve yoksullukla ilgili daha kapsamlı bir analiz sunabilmek üzere çalışmanın bir sonraki bölümünde, GYKA panel verilerinden faydalanarak hane

14 Burada dikkat çeken bir başka bulgu küresel ekonomik krizin tahrip edici etkilerinin yoğun biçimde hissedildiği 2009 yılını takip eden yıllarda çalışan hane reislerinin payının hem yoksul olmayan hem de yoksul hanelerde dïşmesidir.

15 Yoksul olsun olmasın Türkiye'de hane halkı gelirinin büyük bölümü çalışmanın karşıllğı olan emek geliridir. Ancak yine de çalışan yoksul hanelerin emek geliri ile çalışan yoksul olmayan hanelerin emek geliri arasında çok büyük fark vardır. 2005-2011 döneminde yoksul olmayan hanelerin geliri yoksulların yaklaşık 3 katıdır.

16 Yoksul ailelerin toplam geliri içerisindeki Sosyal transfer geliri oranı gelişmiş ülkelere kıyasla Türkiye 'de halen düşük iken bu gelirler, 2006 yılında yoksul hane halkı gelirinin yaklaşık\%24'ünü oluştururken 2011 yılına gelindiğinde aynı oran \%29'a çıkmıştır.

17 Farazi kira gelirlerinin gelir eşitsizliği ve dolayısıly göreli yoksulluk üzerindeki olumlu etkisinden Dayıŏglu ve Başlevent (2006) ve Şeker ve Dayloğlu (2014)'de bahsedilmektedir.

18 Bkz. Taymaz (2009). 
halklarının yoksulluğa giriş ve yoksulluktan çıkış dinamiklerini buraya kadar ele aldığımız hane halkı ve fert özellikleri kapsamında incelemekteyiz.

Daha spesifik olarak, 2005-2011 dönemindeki ikişer yıllık geçişleri kullanarak, hane halklarının yoksulluktan çıkış ve yoksulluğa giriş olasılıklarını iki ayrı probit modelini kullanarak tahmin etmekteyiz. Buna göre yoksulluğa giriş için tahmin edilen modelde bağımlı değişken $t$ - 1 döneminde yoksul olmayıp $t$ döneminde yoksul olan haneler için 1 , her iki dönemde de yoksul olmayan haneler için 0 değerini alan nitel bir değişkendir. Benzer biçimde yoksulluktan çıkış olasılığı için tahmin edilen modelde, bağımlı değişken $t$ - 1 döneminde yoksul olup $t$ döneminde yoksul olmayan haneler için 1, her iki dönemde de yoksul olan haneler için 0 değerini almaktadır. Bu yolla 2005-2011 döneminde 6 farklı geçiş kohortunu (2005-2006, 2006-2007, 2007-2008, 2008-2009, 2009-2010, 2010-2011) havuzlamakta ve probit tahminlerini bu örneklem üzerinden yapmaktayız ${ }^{19}$.

Tablo: 5'de hane halklarının yoksulluktan çıkış ve yoksulluğa giriş olasılıklarında, hane halkı büyüklüğüne, haneye giren gelir türlerine, hane halkı reisinin istihdam durumuna ve eğitim seviyesine ${ }^{20}$ ilişkin değişkenlerin açıklayıcı olarak kullanıldı̆̆ probit modellerinin tahmin sonuçları sunulmaktadır ${ }^{21}$. Buna göre, hane reisinin kadın olması yoksulluktan çıkışı pozitif yönde etkilerken, kadın hane halkı reisinin yoksulluğa geçişte istatistiksel olarak anlamlı bir etkisi yoktur. Hane reisinin yaşı arttıkça hanenin yoksulluktan çıkış olasılığı artarken yoksulluğa geçiş olasılığı azalmaktadır. Bu bulguyu destekleyecek biçimde hane reisinin ilk düzenli işinden beri çalıştığı yıl sayısını ifade eden deneyim yılı hanenin yoksulluğa geçiş riskini azaltmaktadır. Öte yandan hane reisinin yaşının ilerlemesi hanedeki tasarruf oranını artırabilmekte dolayısıyla da yoksulluk riskini azaltabilmektedir. Hane halkı reisinin eğitim düzeyi hanenin yoksulluk geçişleri için oldukça önemli bir rol oynamaktadır. Eğitim düzeyinin yükselmesi, her eğitim düzeyi için giderek artan bir oranda yoksulluktan çıkış olasılığını artırırken yoksulluğa giriş olasılığını azaltmaktadır. Hane reisinin kronik müzmin bir hastalığının olmasının yoksulluktan çıkış üzerinde istatistiksel olarak anlamlı bir etkisi bulunamazken, bu durum hanenin yoksulluk riskini artırmaktadır.

19 2005-2011 dönemindeki ikişer yıllık geçiş olasıllklarını incelememizden ötürü uzun dönemli bir yoksulluk analizi yapmamaktayız. Ancak analizlerimiz yoksulluğa düşen ve yoksulluktan kaçabilen ailelerin karakteristiklerini dinamik bir çerçevede gözlemlemek açısından önemlidir.

20 Stevens (1994) ve Jenkins (2000) gelir ve gelirle ilgili değişkenlerin yoksulluk geçişlerinde en belirgin etkiler yaratan değişkenler olduğunu belirtir.

21 Probit model belirtimleri hem durum değişkenleri (yaş, cinsiyet, eğitim seviyesi, hane halkı büyüklüğü, çocuk saylsı, deneyim, gelir türü) hem de değişim değişkenleri (istihdam durumundaki değişiklikler, iş değişikliği) içermektedir. Yoksulluğa ilişkin geçiş olasılıklarında zaman etkisini kontrol edebilmek için modellere zaman kukla değişkenleri de dâhil edilmiştir. 
Tablo: 5

Yoksulluk Geçişlerini Belirleyen Faktörler

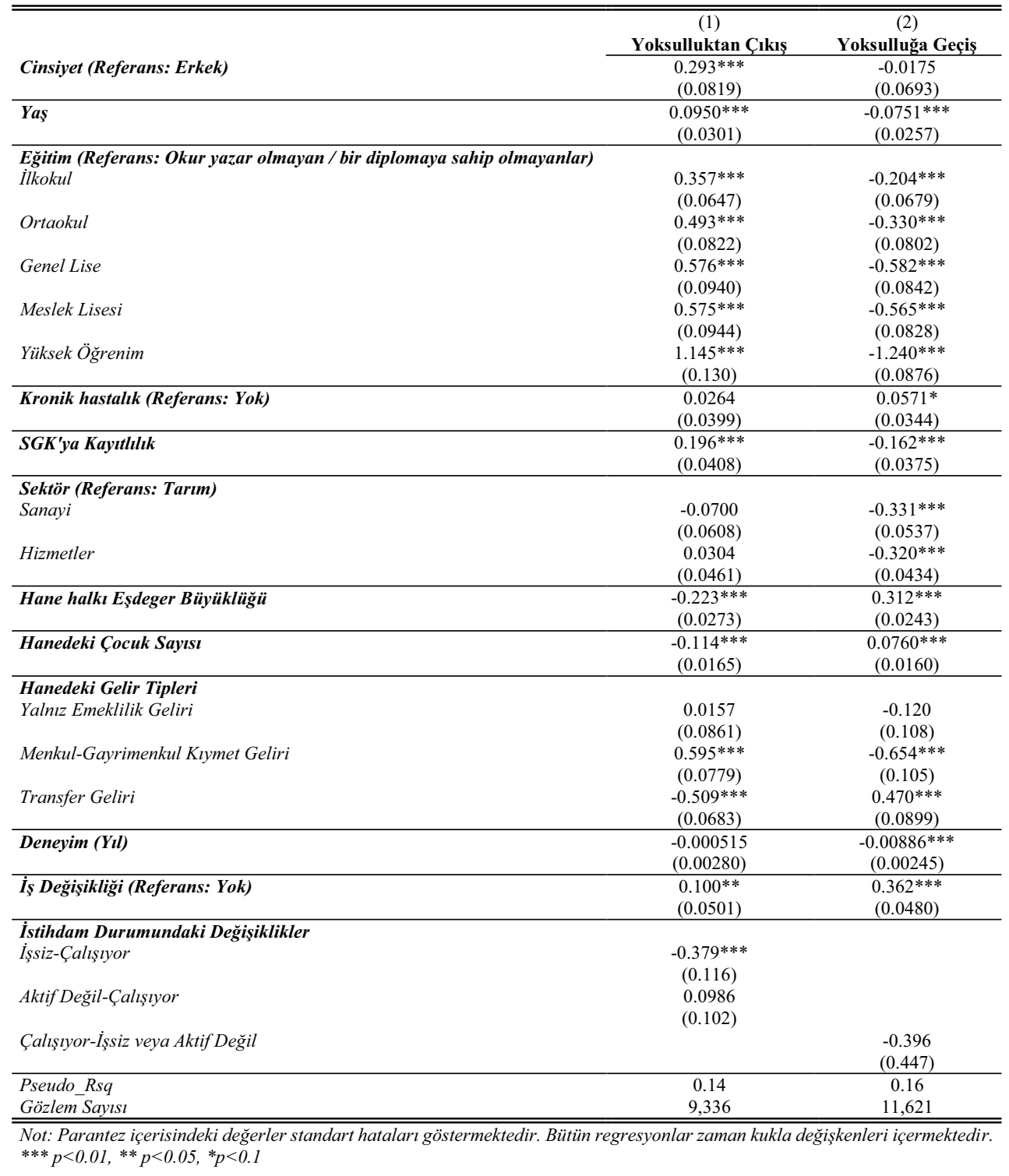


Hane halkı reisinin istihdam durumuyla ilgili değişkenleri incelediğimizde, iş değiștirme durumunun hanelerin hem yoksulluktan çıkma şansını hem de yoksulluğa girme riskini artırdığı görülmektedir. İşsiz olma durumundan çalışan olma durumuna geçiş yoksulluktan çıkma olasılığını sürpriz bir şekilde negatif yönde etkilerken; işgücü piyasasında aktif değilken işe girme durumunun yoksulluktan çıkma üzerinde anlamlı bir etkisi yoktur. Bu durum, işgücü piyasasında aktif ancak işsizlik sigortasından yararlanan fertlerin düşük ücretli işlerde istihdam edilmesi sonucu yoksulluk risklerinin artmasıyla açıklanabilir. İstihdam durumu ile ilgili bir diğer değişiklik olan işsiz kalma ya da işgücünden çekilmenin ise hane halklarının yoksulluk riski üzerinde istatistiksel olarak anlamlı bir etkisi görülememektedir. İstihdam durumundaki olumlu değişiklerin yoksulluk geçişleri üzerindeki etkisi hemen gözlenebilirken işini kaybetme gibi olumsuz değişikliklerin etkisinin tespit edilememesi, bu etkilerin işsizlik sigortası ya da tasarruflara bağlı olarak gecikmeli olarak ortaya çıkmasıyla açıklanabilir. Öte yandan kayıtlı olarak istihdam edilen bir hane halkı reisiyle yaşayan hanelerde yoksulluktan çıkma şansı kayıt dışı olarak istihdam edilenlere göre daha yüksek iken yoksulluk riski daha düşüktür.

Tablo: 5'de ele alınan ve yoksulluk geçişlerini etkilemesi beklenen bir başka faktör hane halkının gelir türleridir ${ }^{22}$. Buna göre, haneye yalnızca emeklilik geliri giriyor olmasının hane halkının yoksulluğa geçiş ya da yoksulluktan çıkışıyla anlamlı bir ilişkisi bulunamamıştır. Emeklilik gelirinin özellikle yoksulluk riskine karşı bireyleri koruması beklenirken bu sonuç emek gelirinden bağımsız olarak hane halklarının servet sahipliğinin yoksul olma ya da olmama üzerinde daha belirleyici olduğuna işaret etmektedir. Bir başka deyişle, düşük emek geliriyle yaşamını idame ettiren bir hane halkı için haneye giren emeklilik gelirinin haneyi daha üst gelir gruplarına taşıma olasılığı oldukça düşüktür. Öte yandan, hanenin menkul ve/veya gayrimenkul kıymet geliri sahipliği yoksulluktan çıkış olasılığını istatistiksel olarak anlamlı bir biçimde artırmakta ve yoksulluğa geçiş olasılığını da azaltmaktadır. Farazi kira geliri sahipliğinin Türkiye'de yoksul ve yoksulluk riski taşıyan hane halkları için önemli bir gelir kaynağı olduğuna Tablo: 4'de değinilmişti ${ }^{23}$.

Tablo: 5'de, Tablo: 4'den farklı olarak yoksulluk geçişlerindeki diğer sosyoekonomik değişkenlerin kontrol edildiği ekonometrik tahmin sonuçları, emeklilik geliri dışındaki diğer transfer gelirlerinin yoksulluk geçişleriyle ilişkisi açısından değerlendirildiğinde ${ }^{24}$; transfer gelirinin yoksulluktan çıkışta yoksulluğa girişe göre daha önemli bir etkiye sahip olduğu görülmektedir. Ancak bizim burada bulduğumuz sonuçlar

Başta Jenkins (2000) ve Stevens (1994) olmak üzere birçok çalışmada gelirle ilgili değişikliklerin yoksulluk geçişlerinde oldukça belirleyici olduğuna değinilmiştir.

23 Şeker ve Dayıŏlu (2014) 2005-2008 döneminde, farazi kira gelirlerini de içeren kira ve menkul klymet gelirlerinin Türkiye'de yoksulluktan çıkışta yüzde 15 oranında sorumlu olduğunu belirtmektedirler.

24 Sosyal transfer gelirleri "hanelerin bazı ihtiyaçlarını karşılamak veya parasal sıkıntılarından dolayı bazı risklerle karşı karşıya kalmaları durumunda devletten veya çeşitli kurum/kuruluşlardan aldıkları ayni veya nakdi karşılıksız yardımlar" olarak tanımlanmakta ve aile-çocuk yardımı, konut yardımı, yaşlılık maaşı, işsizlik maaşı, karşılıksız burslar gibi yardımları içermektedir (bkz. TÜIK GYKA, 2012). 
literatürdeki diğer bazı çalışmaların sonuçlarına göre karşılıksız transfer gelirlerinin aksi yöndeki etkilerine (adverse effects) işaret etmektedir ${ }^{25}$. Tablo: 5'e göre, düşük gelirli hane halklarına yapılan gelir transferleri, Avrupa Birliği ve diğer OECD ülkelerine kıyasla Türkiye'de halen düşük seviyede olmakla birlikte; son 15 yılda bu transferlerde gözlenen yukarı yönlü eğilim² ${ }^{26}$, Türkiye'de işgücü piyasasında caydırıcı etkiler yaratmakta ve bireylerin bu transferlerden faydalanma eğilimini artırarak yoksulluk riskini azaltmaktan ziyade, bireylerin yoksul olarak kalma veya yoksulluk sınırında yaşama olasılığını arttırmaktadır.

Tablo: 5'de, son olarak, yoksulluk geçişleriyle hane halklarının çalıştığ 1 sektörler arasındaki ilişki, geniş bir sektör sınıflaması çerçevesinde ortaya konmaya çalışılmıştır. Buna göre hane halkındaki referans kişinin çalıştığı sektör ile yoksulluktan çıkış olasılığ arasında anlamlı bir ilişki bulunamazken tarım sektöründe çalışmaya göre sırasıyla hizmetler ve sanayi sektöründe çalışıyor olmak yoksulluğa geçiş riskini artan oranda azaltmaktadır. $\mathrm{Bu}$ durum tarımda çalışanların gelir elde etme sürekliliğinin diğer sektörlere oranla daha az olması ile bağlantılı olabileceği gibi yoksulluğa giriş olasılığının en fazla düştüğü sektörün sanayi sektörü olması da benzer biçimde, bu sektörde çalışanların diğer iki sektöre göre daha uzun ve sağlam iş sözleşmelerine tabi olmalarından kaynaklanabilmektedir.

\section{Sonuç}

Temel olarak yoksulluk, eğitimin kalitesi, eğitimde firsat eşitliği, gelir yetersizliği, yaşlılık, engellilik, beceri yetersizliği, eski hükümlü olma gibi mikro nedenlerin yanı sıra; işsizlik, eşitsiz gelir dağılımı, doğal afetler, savaşlar, üretken olmayan nüfus yapısı, yolsuzluklar, yetersiz yeraltı ve yerüstü kaynaklar gibi makro nedenlerle ortaya çıkabilir. Öte yandan yoksulluk bireyin hayatını devam ettirmede zorlanmasına, eğitim ve sağlık gibi temel ihtiyaçlarını karşılayamamasına, suça eğilimli olmasına, psikolojik rahatsızlıklara, sosyal dışlanmaya, çocuk işçiliğinde artışa ve sosyal yapının bozulmasına yol açabilir.

25 Bane ve Ellwood (1986), ABD için Layte ve Whelan (2002) ise Hollanda için yaptıkları çalı̧smalarında transfer gelirlerinin olumlu etkisinin yoksulluktan çıkışta yoksulluğa girişe göre daha belirgin olduğunu göstermektedirler. Şeker ve Dayloğlu (2014) ve Sarlsoy ve Koç (2010) Türkiye'de transfer gelirlerinin yoksulluk dinamikleri üzerindeki olumlu etkisine işaret etmektedirler.

26 Genel Bütçeden hane halklarına yapılan transferler incelendiğinde özellikle 2008 yılından itibaren büyük ölçeklerde kaynak transferi yapıldlğı görülmektedir. 2008 yllından itibaren bu kalemlerde kaydedilen artı̧̧ sonucu, 2012 yılında 8,7 Milyar TL, 2013 yllında ise 10,7 Milyar TL sosyal transfer yapıldı̆̆ görülmektedir. Mutlak yoksulluğa yönelik ve yoksul kesimin temel ihtiyaçların gidermeyi hedefleyen sağlık, barımma ve yiyecek kalemlerinin toplamina ayrica bakllırsa, Genel Bütçe Toplam Cari Transferlerin içerisinde çok küçük bir paya sahip bu kalemlerin yıllar itibariyle kismi de olsa nominal olarak arttı̆̆ görülmektedir. Genel bütçeden hane halklarına yapılan sağllk, barınma ve yiyecek amaçlı transferlerin GSYİH'ye oranı 2003'deki yüzde 0.6'lkk değerinden 2011'de yüzde 1.2'ye yükselmiştir. 
(Odabaşı, 2009). Yoksulluğu ortaya çıkaran nedenler, sonuçları ve yoksullukla mücadele politikaları bilim adamları kadar, politikacıların da odak noktasını oluşturmaktadır.

Bu çalışmada Türkiye için Gelir ve Yaşam Koşulları Araştırmaları'ndan (GYKA) elde edilen verilerle 2005-2011 dönemi için yoksulluğun profili analiz edilmektedir. İlgili dönemde her yıl için yoksulluk sınırı, yoksulluk oranı ve yoksulluk açığı hesaplanmış ve hane halkı ve bireylere ilişkin demografik, ekonomik ve sosyal nitelikler çerçevesinde yoksul ve yoksul olmayanların durumu değerlendirilmiştir. Daha sonra bir probit model yardımıyla hane halkına ilişkin söz konusu faktörlerin yoksulluğa giriş ve yoksulluktan çıkış üzerindeki etkileri araştırılmıştır.

Çalışmadan elde edilen sonuçlar, söz konusu dönemde Türkiye'de yoksulluk oranında bir düşüşe işaret etse de göreli yoksulluk göz önüne alındığında, halen çok yüksek sayıda insanın yoksul olması son dönemde gerçekleşen ekonomik büyümeden yoksul hane halklarının yeterince yararlanamadığını göstermektedir. Yoksulluk açı̆̆ı oranı ilgili dönemde azalma göstermiştir ancak gelişmiş ülkelerle kıyaslandığında hala yüksek orandadır. Bu durum Türkiye'de yoksullar arasındaki eşitsizliğin de yüksek olduğunu belirtmektedir. Yoksulluk analizlerinde hane halkının yapısı daha yakından incelendiğinde, literatürdeki diğer çalışmalarla benzer şekilde kalabalık ailelerin yoksulluk riskinin daha yüksek olduğu, sosyal güvenlik sisteminden yoksun olmanın yoksulluk riskini arttırdığı, hane halkı reisinin kadın olmasının ve eğitim seviyesindeki artışın yoksulluk riskini azalttığı sonuçlarına ulaşılmıştır.

Hane halklarının yoksulluktan çıkış ve yoksulluğa giriş olasılıklarının incelendiği probit modellerinden, hane reisinin kadın olmasının yoksulluktan çıkışı pozitif yönde etkilediği, hane reisinin yaşı arttıkça hanenin yoksulluktan çıkış olasılığının arttığı ve eğitim düzeyindeki artışın yoksulluktan çıkış olasılığını arttırdı̆̆ 1 elde edilen temel sonuçlar arasındadır. Hane reisinin kronik müzmin bir hastalığının olmasının yoksulluktan çıkış üzerinde istatistiksel olarak anlamlı bir etkisi bulunamazken, bu durum hanenin yoksulluk riskini artırmaktadır. Öte yandan Türkiye üzerine var olan literatürden farklı olarak düşük gelirli hane halklarına yapılan gelir transferlerinin, Türkiye'de işgücü piyasasında caydırıcı etkiler yaratmakta olduğu ve son on yılda artan bu transferlerin yoksulluk riskini azaltmaktan ziyade bireylerin yoksul olarak kalma veya yoksulluk sınırında yaşama olasılığını arttırdığ bulgusuna ulaşılmıştır.

Yoksullukla ilgili bu tespitlerinin ardından izlenebilecek politika önerileri şu şekilde sıralanabilir. Her şeyden önce yoksulluk bir gelir kıtlığı durumudur. Bu kıtlı̆̆ aşmanın en önemli koşulu ise istikrarlı bir ekonomik büyüme ile birlikte adil bir gelir dağılımıdır. Bu çerçevede, kalkınma politikaları gözden geçirilebilir ve gelirin yeniden dağıtımı için etkin maliye politikaları izlenebilir. Önceki çalışmalarda da belirtildiği gibi, eğitimde firsat eşitsizliği yoksulluğu körüklemektedir. Yoksulluktan çıkışları hızlandırabilmek için nitelikli ve adaletli eğitim politikalarına önem verilebilir. Kalabalık ailelerin yoksul olma riski yüksektir. Bu nedenle nüfus politikaları gözden geçirilmelidir. 
Niceliksel olarak nüfus artışından ziyade nüfusun ve beşeri sermayenin etkinliği hususunda çalışmalar yapılabilir. Herhangi bir sosyal güvenlik sistemine kayıtlı olmayanlar da yoksulluk riskini daha fazla hissetmektedirler. $\mathrm{Bu}$ nedenle kayıt dışı istihdamın önüne geçmek için etkin politikalar izlenebilir.

\section{Kaynakça}

Acar, A. \& C. Başlevent (2014), "Examination of the Transition of Turkish Households into and Out of Poverty between 2007-2010", Betam Working Paper Series, 15.

Addabbo, T. (2000), "Poverty Dynamics: Analysis of Household Incomes in Italy", Labour, 14(1), $119-144$

Andriopoulou, E. \& P. Tsakloglou (2011), "The Determinants of Poverty Transitions in Europe and the Role of Duration Dependence", IZA DiscussionPapers, 5692.

Aran, M.A. \& S. Demir \& Ö. Sarıca \& H. Yazıcı (2010), "Poverty and Inequality Changes in Turkey (2003-2006)", State Planning Organization of the Republic of Turkey and World Bank Social Policy Analytical Work Program, Working Paper 1, Ankara.

Atkinson, A.B. (1975), The Economics of Inequality, Oxford: Oxford University Press.

Azevedo, J.P. \& A. Atamanov (2014), "Pathways to the Middle Class in Turkey: How Have Reducing Poverty and Boosting Shared Prosperity Helped?", World Bank Policy Research Working Paper, 6834.

Bane, M.J. \& D.T. Ellwood (1986), "Slipping into and out of Poverty: The Dynamics of Spells", Journal of Human Resources, 21(1), 1-23.

Buddelmeyer, H. \& S. Verick (2007), "Understanding the Drivers of Poverty Dynamics in Australian Households", IZA Discussion Papers, 2827.

Dayığlu, M. \& C. Başlevent (2006), "Imputed Rents and Regional Income Inequality in Turkey: A Subgroup Decomposition of the Atkinson Index", Regional Studies, 40(8), 889-905.

Güloğlu, T. \& K. Aydın \& F.K. Güloğlu (2012), "Relative Poverty in Turkey between 1994 and 2006", Economics and Management, 17(1), 163-175.

Gürsel, S. \& A. Acar (2015), “Türkiye'de Yoksulluk Dinamikleri”, Betam Araştırma Notu, 15/175, 29 Ocak.

Gürses, D. (2007), “Türkiye'de Yoksulluk Ve Yoksullukla Mücadele Politikaları”, Balıkesir Üniversitesi Sosyal Bilimler Dergisi, 17(1), 59-74.

Güven, A. \& B. Dalgıç \& A. Tansel (2014), "Gelir Hareketliliği Eşitsizlikleri Azaltabilir Mi? Türkiye Örneği”, Türkiye Ekonomi Kurumu Tartışma Metni, 2014/7, Temmuz.

Jenkins, S.P. (2000), “Modelling Household Income Dynamics”, Journal of Population of Economics, 13, 529-567.

Layte, R. \& C.T. Whealan (2002), "Moving in and out of Poverty: the Impact of Welfare Regimes on Poverty Dynamics in the EU", EPAG Working Paper, 2002-30, University of Essex, Colchester.

Martin, E.B. \& F.A. Cowell (2006), "Static and Dynamic Poverty in Spain, 1993-2000”, Revista de Economia Publica, 179 (4), 51-77. 
McKernan, S.M. \& C. Ratchliffe (2005), "Events that Trigger Poverty Entries and Exits”, Social Science Quarterly, 86 (supplement), 1146-1169.

Odabaşı, F. (2009), "Yoksullukla Mücadelede İstihdamın Rolü”, Sosyal Yardım Uzmanlık Tezi, T.C. Başbakanlık Sosyal Yardımlaşma ve Dayanışma Genel Müdürlüğü, Ankara.

OECD (2010), Economic, Environmental and Social Statistics, $<\mathrm{http}: / /$ www.oecdilibrary.org/economics/oecd-factbook-2010_factbook-2010-en>, 02.03.2015.

OECD (2012 \& 2014), Economic Surveys: Turkey, OECD Publishing, July.

Polin, V. \& M. Raitano (2012), Poverty Dynamics in Clusters of European Union Countries: Related Events and Main Determinants, University of Verona, WP.10.

Sarısoy, İ. \& S. Koç (2010), "Türkiye'de Kamu Sosyal Transfer Harcamalarının Yoksulluğu Azaltmadaki Etkilerinin Ekonometrik Analizi”, Maliye Dergisi, 158, Ocak-Haziran, 327348.

Stevens, A.H. (1994), “The Dynamics of Poverty Spells: Updating Bane and Ellwood”, The American Economic Review, 84(2), 34-37.

Şeker, D.S. \& M. Dayığlu (2014), "Poverty Dynamics in Turkey”, Review of Income and Wealth", DOI: 10.1111 /roiw.12112.

Şeker, D.S. \& S.P. Jenkins (2013), "Poverty Trends in Turkey”, IZA Discussion Paper, 7823.

Şenses, F. (2009), Küreselleşmenin Öteki Yüzü Yoksulluk, İletişim Yayınları, İstanbul.

Taymaz, E. (2009), "Informality and Productivity: Productivity Differentials between Formal and Informal Firms in Turkey", Country Economic Memorandum (CEM) - Informality: Causes, Consequences, Policies, June.

TUİK (2013), Yoksulluk Çalışması, <http://www.tuik.gov.tr/PreHaberbultenleri.do?id=16204>, 02.03.2015.

United Nations (2011), "Indicators of Poverty\&Hunger", $<$ http://www.un.org/esa/socdev/unyin/documents/ydiDavidGordon_poverty.pdf>, 02.03.2015.

United Nations (2015), "Human Development Reports", <http://hdr.undp.org/en/content/table-2human-development-index-trends-1980-2013>, 02.03.2015.

Valetta, R.G. (2006), "The Ins and Outs of Poverty in Advanced Economies: Government Policy and Poverty Dynamics in Canada, Germany, Great Britain, and the United States", Review of Income and Health, 52(2), 261-284.

World Bank, (2005), Introduction to Poverty Analysis, World Bank, Washington.

World Bank (2014), Poverty Overview, <http://www.worldbank.org/en/topic/poverty/overview>, 02.03.2015.

World Bank (2015), Poverty and Equity Data, <http://povertydata.worldbank.org/poverty/home>, 02.03.2015.

Yükseler, Z. \& E. Türkan (2007), “Türkiye'de Hane halkı: İşgücü, Gelir, Harcama ve Yoksulluk Açısından Analizi”, Türkiye Ekonomi Kurumu Tartışma Metni, 2007/4, Haziran. 